The National Conference of Literature and Religion was founded to explore the borders between the study of theology and the study of literature. The essays in this book are drawn from the first meeting of the Conference and while they are deliberately diverse, they are united by a common concern to seek in the imaginative and metaphorical world of literature for a lively and perhaps radical expression of religious faith and belief.

The topics covered include the modern American writers Joan Didion and Flannery O'Connor, whose 'experience of mystery' must be mediated through the manners of a literary artifact; W. H. Auden and George Herbert are examined from the point of view of the border of literature and Christian devotion, spirituality and the life of prayer; while Simone Weil, who interpreted her own life and death in terms of the sacrifice of Christ, gives rise to a discussion of 'sacrificial suffering' in a writer.

Other essays range across a wide expanse of Western literature, from the Book of Job and Greek tragedy to the English Romantic poets and George Eliot. Finally, attention is given to more general problems which are raised when religion and literature attempt to focus on common concerns: the problem of religious commitment in art; of exegesis; and the nature and theory of narrative.

As a whole the book raises issues which are of deep interest to theologians and churchmen and women, students of literature and anyone concerned with the matter of exploring a communicating religious belief in the modern world.

\title{
The editor
}

David Jasper is Fellow and Chaplain of Hatfield College, Durham. He graduated in English from Jesus College, Cambridge, and subsequently trained for the Anglican ministry at St Stephen's House, Oxford, where he also took a degree in theology.

$\mathrm{He}$ has published articles on literature and religion in various journals and periodicals. 


\title{
IMAGES OF BELIEF IN LITERATURE
}

Edited by

\author{
David Jasper \\ Fellow and Chaplain \\ Hatfield College, Durham
}

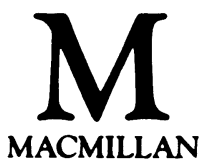


(C) David Jasper 1984

Softcover reprint of the hardcover 1st edition 1984 978-0-333-36401-7

All rights reserved. No part of this publication may be reproduced or transmitted, in any form or by any means, without permission

First published 1984 by

THE MACMILLAN PRESS LTD

London and Basingstoke

Companies and representatives throughout the world

British Library Cataloguing in Publication Data

Jasper, David

Images of belief in literature.

1. Religion and literature-Congresses

I. Title

$801 \quad$ PR 145

ISBN 978-1-349-17494-2

DOI 10.1007/978-1-349-17492-8

ISBN 978-1-349-17492-8 (eBook) 


\section{Contents}

Notes on the Contributors vi

Acknowledgements vii

Preface ix

Introduction $\quad$ F. W. Dillistone 1

1 Religion and Imagination John Coulson 7

2 Mystery and Mediation: Reflections on Flannery

O'Connor and Joan Didion $\quad$ D. Z. Phillips 24

3 Job and Sophocles Ulrich Simon 42

4 W. H. Auden: Horae Canonicae: Auden's Vision of a Rood A Study in Coherence Peter Walker 52

5 Poetry and Prophecy: Bishop Lowth and the Hebrew Scriptures in Eighteenth-century England

Stephen Prickett 81

6 Literature and Commitment: 'Choosing Sides'

Martin Jarrett-Kerr 104

7 Simone Weil-Sacrifice: A Problem for Theology

Ann Loades 122

8 Middlemarch as a Religious Novel, or Life without God

T. R. Wright 138

9 'Heaven's Lidger Here': Herbert's Temple and Seventeenth-century Devotion Helen Wilcox 153

10 Exegesis: Literary and Divine Dominic Baker-Smith 169

11 Story: Towards a Christian Theory of Narrative

Michael Edwards 179

Index 


\section{Notes on the Contributors}

Dominic BaKeR-SMith is Professor of English, Universiteit van Amsterdam.

John Coulson is Senior Lecturer in the Department of Theology, University of Bristol.

F. W. Dillistone is Canon Emeritus of Liverpool Cathedral and Fellow Emeritus of Oriel College, Oxford. He is President of the National Conference on Literature and Religion.

Michael E dwards is Reader in Literature, University of Essex.

MARTIN JARRETT-KerR was formerly Associate Lecturer in the Department of Theology and the School of English, University of Leeds. He is now of the Community of the Resurrection, Mirfield.

David Jasper is Chaplain and Harris Fellow of Hatfield College, University of Durham.

AnN L. LoAdes is Senior Lecturer in Theology, University of Durham.

D. Z. Phillips is Professor of Philosophy at the University College of Swansea.

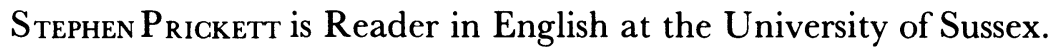

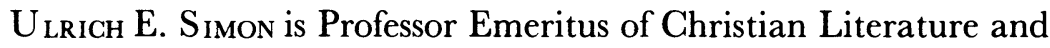
Dean Emeritus of King's College, London.

Peter Walker is the Bishop of Ely.

HeLEN W ILCOX is Lecturer in English at the University of Liverpool, and currently editing Herbert's poems for the Longman Annotated English Poets.

T. R. W RIGHT is Lecturer in English at the University of Newcastleupon-Tyne. 


\section{Acknowledgements}

The author and publishers wish to thank the following who have kindly given permission for the use of copyright material:

Faber and Faber Ltd and Random House Inc. for extracts from 'Horae Canonicae' in W. H. Auden: Collected Poems edited by Edward Mendelson;

Farrar, Straus \& Giroux Inc. and Wallace \& Shiel Agency Inc. for extracts from Slouching Towards Bethlehem by Joan Didion, copyright (C) 1965, 1966, 1967, 1968 by Joan Didion;

Farrar, Straus \& Giroux Inc. and A. D. Peters \& Co. Ltd on behalf of the Estate of Mary Flannery O'Connor for extracts from 'Revelation' in Everything that Rises Must Converge by Flannery O'Connor. US copyright (C) 1961, 1965 by the Executors. 


\section{Preface}

The papers in this Symposium were read at the first National Conference on Literature and Religion in Durham, 23-25 September 1982. They are evidence of the wide range of interests which were represented at the Conference - theologians and literary critics, philosophers and churchmen. Each paper is individual and self-sufficient, yet the collection as a whole sets in motion a series of cross-currents, as tools of different disciplines engage matter of common interest in sacred and secular literature. A coherent attention, therefore, comes to be given to such key issues for both theology and literature as revelation, imagination, commitment and prophecy.

The joint study of literature and theology has for some years flourished in the United States, and the Conference was honoured by the presence of Professor Robert G. Collmer of Baylor University, Texas, the President of the American Conference on Christianity and Literature. It is our hope to begin to draw together the considerable amount of work in this field at present being carried out on this side of the Atlantic, to give it focus and to foster fruitful discussion.

Part of Stephen Prickett's paper was published in Centrum, Spring 1981. Michael Edwards' paper is to appear as part of a book, Towards a Christian Poetics, to be published by Macmillan in 1984 . My editorial duties have been eased immensely by the help of Professor J. R. Watson and Mrs M. M. Gilley. Thanks are also due to Mrs Frances Durkin, who typed the final script and to Christopher Helliwell who prepared the index. 